\title{
DEBATES
}

\section{A Utopia de Thomas More e a questão republicana}

\author{
Thomas More's Utopia and the republican issue
}

\section{Gleyton Trindade}

\section{Resumo}

Este artigo realiza uma revisão bibliográfica procurando analisar o significado da obra Utopia, de Thomas More, com base nos trabalhos que metodologicamente valorizam o "contexto intelectual" de uma obra. Adotando um ponto de vista crítico em relação às leituras liberais da Utopia, o artigo procura destacar os avanços do que estamos designando como leituras republicanas, em seu esforço de inserir a obra de More nos debates de seu tempo. Concluímos que a grande contribuição da Utopia para pensar os desafios políticos, inclusive no mundo contemporâneo, não está no que ela prefiguraria de um possível regime totalitário, como afirmaria a leitura liberal, mas na necessidade de refletir sobre a constituição de uma república de homens livres nas condiçóes de regimes políticos ameaçados pelo poder econômico.

\section{Palavras-chave}

Thomas More; Utopia; Liberalismo; Republicanismo.

\begin{abstract}
This article realizes a bibliographical review looking to analyze the meaning of Thomas More 's Utopia, based on works that methodologically value the "intellectual context" of a work. Taking a critical view of the liberal readings of Utopia, the article seeks to highlight the advances of what we are designating as republican readings in their effort to embed More's work in the debates of his time. We conclude that Utopia's great contribution to thinking about political challenges, including in the contemporary world, is not in what it would foreshadow of a possible totalitarian regime, as the liberal reading would affirm, but in the need to reflect on the constitution of a republic of free men under the conditions of political regimes threatened by economic power.
\end{abstract}

\section{Keywords}

Thomas More; Utopia; Liberalism; Republicanism. 


\section{Introdução}

Completados 500 anos de sua publicaçáo, a Utopia, de Thomas More, continua nos interrogando sobre seus significados e sobre os desafios políticos suscitados por sua reflexão política ${ }^{1}$. O interesse e a curiosidade sobre esta obra clássica podem ser verificados num conjunto bastante variado de publicaçóes recentes sobre seu legado, incluindo a edição recente de sua primeira edição em língua portuguesa traduzida diretamente do latim, língua em que foi originalmente produzida (MORE, 2017). No entanto, cinco séculos de leituras e camadas interpretativas sobre uma obra clássica, frequentemente impóe desafios aos leitores contemporâneos interessados nos detalhes mais originais de seu legado. Não raramente tais leitores se vêm confrontados com uma interpretaçáa da Utopia centrada na denúncia de que o projeto utópico traria consigo os riscos da implantação de uma sociedade de vigilância constante, prefiguração, portanto, das ameaças impostas pelos regimes totalitários. Em tais interpretaçôes, a chave de leitura mais importante da obra de More seria aquela que compreende os riscos às liberdades individuais em projetos de sociedades perfeitas, como a que seria exposta na Utopia. Estas interpretaçóes, que poderíamos designar como uma leitura liberal da Utopia, seriam caracterizadas por dois elementos importantes: a crítica ao ideal de "perfectibilidade" e a suposição de uma sociedade "a-histórica" supostamente contidas na obra moreana.

Diferentemente, neste artigo defendemos a ideia de que, por um lado, as leituras liberais da Utopia seriam limitadas ao compreender o significado desta obra clássica. Desta forma, a acusaçáo ao pretenso perfeccionismo e ao a-historicismo de More não fariam justiça às leituras mais generosas da noção de perfeccionismo e muito menos aos detalhes da própria obra moreana. Por outro lado, pretendemos demonstrar que os avanços contemporâneos das leituras da "Utopia" não nos permitiriam esta postura, que consideramos anacrônica ao retirar a obra de seu contexto histórico e intelectual, recusando a compreensão de seu lugar nos debates políticos e intelectuais de seu tempo. Por isto, o trabalho parte para a adoção das leituras mais contemporâneas, o que estamos definindo como leituras republicanas, como forma de acentuar os significados da Utopia na sua filiação às tradiçôes políticas

\footnotetext{
${ }^{1}$ Este texto é uma versão revista e ampliada de trabalho apresentado em evento de celebração dos 500 anos de publicação da Utopia. Tal evento ocorreu na Universidade Federal de Alfenas em outubro de 2016 e foi organizado pelo grupo de pesquisa Filosofia, História e Teoria Social. Deixo aqui meu agradecimento aos membros do grupo pelas discussões que levaram a esta reflexão.
} 
e de pensamento de seu tempo. Tais abordagens nos permitiriam compreender a maneira como More pretende se associar ou desarticular determinadas tradiçóes políticas, revelando as sutilezas e significados da obra. Desta leitura emerge a preocupação de More com o melhor desenho para a República e as virtudes que os cidadãos deveriam cultivar para nelas viver como questóes fundamentais que a Utopia deixaria como legado, náo apenas para seu tempo, mas também para aqueles que pretendem pensar os desafios políticos do mundo contemporâneo.

\section{Leituras republicanas da Utopia}

É preciso reconhecer que aquilo que designamos aqui como leituras liberais da Utopia possuem raízes filosóficas mais profundas. Elas derivam, basicamente, dos ataques liberais aos regimes totalitários do século XX realizados, entre outros, por autores como Berlin (1978) e Popper (1987), mas suas raízes poderiam ser encontradas ainda no século XIX na crítica liberal à incompatibilidade dos chamados projetos utópicos à realidade das sociedades modernas e sua preocupação com a defesa dos direitos individuais, a partir da qual os movimentos socialistas também recusariam sua filiação aos movimentos utópicos (LEOPOLD, 2007). Nesta perspectiva, a Utopia seria atacada, basicamente, por prefigurar as sociedades totalitárias que surgiriam séculos depois de sua própria publicação. Estariam presentes na obra moreana os princípios racionais portadores dos germes da experiência totalitária a saber: o ideal de "perfectibilidade" social, que torna a própria sociedade massa manipulável para o poder em busca de uma perfeição inatingível; e o ideal de uma sociedade a-histórica já que, uma vez alcançada a perfeição, ela se constituiria como experiência social imutável, fora da própria história ${ }^{2}$.

Tal tipo de leitura, ao remeter a Utopia à genealogia do totalitarismo, faria teóricos como Shklar (1965) e Abensour (1990) se perguntarem sobre a questão de nossos contemporâneos não saberem mais ler as utopias, em especial a obra clássica de More. O desencontro contemporâneo com a literatura utópica se assentaria na própria incompreensão sobre o tipo de saber ali desenvolvido. Não tratar-se-ia de um tipo de conhecimento expresso em formulaçóes conclusivas e passíveis de implementação e verificação empírica, como se poderia erroneamente supor. Para nos prevenir contra modos de leitura grosseiramente inadequados como este, Abensour nos aconselharia a tomar a obra moreana a partir da observaçáo de Platáo, sobre o

\footnotetext{
2 Para leituras mais generosas do utopismo e sua história ver, entre outros, Rothstein; Muschamp; Marty (2003), Kumar (2003) Sargent (2006), Fraga (2014) e Sargent (2016).
} 
desvirtuamento de seu pensamento realizado pelo tirano de Siracusa: trata-se de um saber que não se pode simplesmente formular em proposiçóes. Dito de outro modo, a crítica contemporânea constantemente incorreria no erro de tomar a Utopia como um plano de constituição, um projeto de sociedade, um conjunto de formulaçóes que poderiam ser diretamente extraídas do texto e demandariam implementação prática sem perceber que, na verdade, a obra seria fruto de um dispositivo textual complexo, apontando muito mais para grandes interrogaçôes na tradição do pensamento político ocidental, que para conclusóes imediatas. Deste ponto de vista, qualquer leitura que não compreenda este dispositivo textual, estaria imediatamente fadada a permanecer aquém dos desafios suscitados pela Utopia.

Partindo de leituras que buscariam encontrar na Utopia um programa político acabado, não seria estranho encontrar nos teóricos socialistas de várias vertentes a rejeição de sua filiação ao projeto utópico. Como observa Leopold (2007), embora seja perfeitamente familiar e até mesmo lugar comum associar-se socialismo e utopia, tal associação parte, normalmente, de fora da tradição socialista, ou seja, é realizada por não socialistas, carregando, muitas vezes, grande carga pejorativa. No mesmo sentido, os próprios socialistas seriam tipicamente resistentes a este tipo de descriçáo, rejeitando a associaçáo do socialismo, propriamente compreendido, com a utopia ${ }^{3}$. No campo da sociologia, mesmo aqueles teóricos que incorporariam a noçáo de utopia como elemento explicativo da realidade social, como no caso exemplar de Manheim, ainda assim rejeitariam sumariamente Tomas More, considerado uma figura de pouco significado na história real do pensamento utópico (SHKLAR, 1965).

Diferentemente, podemos sustentar que as mais ricas leituras contemporâneas de More são aquelas que inserem sua obra no contexto político e intelectual de seu tempo, buscando compreender como sua reflexão se posiciona em relação às tradiçóes políticas e correntes de pensamento com as quais teve contato, em que medida se filiou ou procurou desarticular determinadas correntes de opiniáo. Tal abordagem permite avaliar o significado das novidades sugeridas pela obra, em relaçáo ao que existia em seu tempo; além de apontar para o conjunto de problemas legado por ela à posteridade. Deste ponto de vista, diferentemente de uma postura que enxerga na

\footnotetext{
${ }^{3}$ Leopold (2007) faz referência à conhecida distinção entre socialismo utópico e científico apresentada por Marx e Engels, mas mostra como visão semelhante poderia ser encontrada em correntes socialistas diferentes como no Fabianismo. Shklar (1965, p. 368) se lembra que, na tradição marxista, Kautsky seria um dos poucos a saudar Thomas More como um dos primeiros socialistas da história.
} 
Utopia uma prefiguração dos regimes totalitários do século XX, seria necessário, antes de tudo, inserir o pensamento de More entre os chamados studia humanitatis dos séculos XV e XVI e apreender o lugar de sua obra entre os debates desta tradição ${ }^{4}$. Significaria, portanto, tomar seriamente o subtítulo da Utopia, optimo republicae statu, para compreender que More pretendia se inserir nos debates do chamado Renascimento europeu, a partir de uma longa tradição do pensamento político interessado no conhecimento sobre as instituiçôes que organizam uma República de homens livres, e na reflexão sobre as virtudes que tais homens livres deveriam cultivar para fundar e manter uma ordem política justa ${ }^{5}$. Estes seriam os fundamentos do que estamos designando como leituras "republicanas" da Utopia.

Deste ponto de vista, como apontam Logan e Adams (2002), o problema, a forma e a estrutura da Utopia derivam profundamente do humanismo dos studia humanitatis renascentistas trilhando um gênero de escrita política inaugurado ainda por Platão, na República; por Aristóteles, em A Política; e retomada por autores romanos, como Tácito e Plutarco. No entanto, diferentemente das obras platônicas e aristotélicas que utilizavam recursos puramente argumentativos, More acrescentará o recurso do relato de viagem, estilo revalorizado em função das grandes viagens marítimas. Nesta perspectiva, pensar a melhor república envolveria a construçáo argumentativa num método que iria além do ato descritivo das características desejáveis para uma república justa. Antes, a premissa norteadora para o desenho da melhor república seria o da autarkeia, autossuficiência, elaborado por Platáo e refinado posteriormente por Aristóteles. A partir do princípio da autarkeia, quatro passos fundamentais deveriam ser dados na reflexão sobre a república ideal. $\mathrm{O}$ primeiro consistia em determinar o que constituiria a felicidade para o indivíduo, questão central da teoria ética, como expõe Aristóteles no livro VII Da Política. A partir das conclusôes sobre a boa vida desejável para os indivíduos, os teóricos derivariam os objetivos comuns a serem alcançados pelos cidadáos que vivem juntos numa politeia, a fim de garantir a felicidade dos cidadáos. $\mathrm{O}$ terceiro passo consistiria em descrever um conjunto de condiçóes físicas e institucionais requeridas pela república, fatores como: tamanho da população, extensão territorial, certas funçôes

\footnotetext{
${ }^{4}$ Os studia humanitatis era como Cícero se referiria aos estudos de retórica e política, expressão popularizada pelos humanistas renascentistas posteriormente.

${ }^{5}$ Para o leitor brasileiro a compreensão deste aspecto se reveste da dificuldade adicional do fato de que, incrivelmente, a edição brasileira da Utopia de maior circulação no país omite o subtítulo original do livro. Ver More (1988) e comparar com More (2002).
} 
ocupacionais, compatíveis com a realização da felicidade de todos. Finalmente, os teóricos descreveriam uma forma particular em que estes componentes deveriam se combinar para constituir a melhor das repúblicas.

More compartilha deste método clássico de análise, a respeito da melhor forma de governo. Como se sabe, a Utopia está organizada em dois livros. No Livro I, escrito no estilo do diálogo platônico, reformulado por Cícero ao utilizar diálogos com longos discursos pontuados por pequenas intervençôes, somos apresentados à figura fictícia de Rafael Hitlodeu, viajante português que serviu à Américo Vespúcio. Participam ainda do diálogo o próprio Thomas More, então enviado diplomático do rei da Inglaterra à Antuérpia e seu amigo Peter Giles. Ainda neste primeiro livro, Hitlodeu disserta sobre os problemas sociais que tantos males e desordens causam às naçôes cristâs europeias e debate com More a questão da utilidade ou não do filósofo servir, com seu conhecimento, a um príncipe nas artes de governar. Desta maneira, More retomaria o tema platônico do rei filósofo, ou seja, da necessidade de que poder político e filosofia se encontrem na mesma cabeça, a fim de evitar os males do Estado, mas numa hipótese atenuada ao afirmar a possibilidade do filósofo conselheiro do príncipe. Negando a utilidade de tal ofício, Hitlodeu denunciará a versão de More como impraticável, servindo apenas como uma soluçáo precária da aporia platônica uma vez que, permanecendo filósofo e príncipe como cabeças diferentes, ergue-se entre eles o obstáculo intransponível da opinião. Segue-se, no Livro II, o relato de Hitlodeu sobre as instituiçôes da República da Utopia e suas fortes bases igualitárias e comunistas e, ao final, os breves comentários de More desejando ver reproduzidas na Europa algumas daquelas instituiçôes, mas, ao mesmo tempo, reconhecendo a dificuldade de que isto aconteça ${ }^{6}$.

Havia pouca discordância, portanto, em relação ao que constituía a optimus status republicae. De maneira geral, ela era associada à existência de leis justas que serviam para promover o bem comum e dos cidadáos. Consequentemente, uma república justa seria aquela em que os cidadãos seriam capazes de buscar sua própria felicidade vivendo a boa vida em benefício de si mesmo e de todos (SKINNER, 2003). As discordâncias começavam quando se tratava de definir o modo através do qual tal república deveria ser alcançada, uma vez que grandes diferenças de opinião

\footnotetext{
${ }^{6}$ Há um longo debate sobre a estrutura da Utopia que não é possível reproduzir no espaço deste artigo. Tais debates envolvem desde o reconhecimento de que os livros I e II foram escritos em diferentes épocas até a suposição, pouco crível, de que teriam sido redigidos por autores diferentes. Para a análise destas questóes veja-se Logan e Adams (2002) e Skinner (1997).
} 
existiam em relação à forma de governo mais adequada para realizá-la. No tempo em que More redige sua Utopia, correntes de pensamento e tradiçóes políticas se organizavam em relação às diferentes respostas para esta questão, se orientando até mesmo em função das diferentes fontes filosóficas mobilizadas a favor de seu posicionamento.

Em relação às fontes filosóficas, boa parte da teoria política republicana contemporânea tem destacado as diferenças entre as matrizes do republicanismo de inspiração grega comparativamente ao de inspiração romana, especialmente no que diz respeito ao conceito de liberdade (PETTIT, 1997; SKINNER, 1999; HONOHAN, 2003). More claramente insere sua Utopia neste debate. Lembremos que Rafael Hitlodeu é apresentado no Livro I como um filósofo do tipo grego que dá muito menos importância aos escritores latinos. Caberia também a Hitlodeu a defesa de uma concepção platônica da vita contemplativa na polêmica sobre a participaçáo dos filósofos como conselheiros dos príncipes, recebendo, por sua vez, a discordância do próprio More.

$\mathrm{Na}$ verdade, no que diz respeito à defesa de uma concepção do governo misto, existiria uma clara continuidade entre as matrizes do republicanismo grego e romano no pensamento renascentista. $\mathrm{O}$ ponto de desacordo principal entre eles poderia ser encontrado na concepçáo de cidadania e no significado da liberdade. $\mathrm{Na}$ matriz grega, a cidadania seria identificada com uma capacidade que é a de se autogovernar. Esta capacidade significa que os cidadãos são indivíduos dotados de características particulares através das quais podem ser considerados qualificados para a cidadania. Neste sentido, um indivíduo é qualificado para ser cidadáo se possui a virtude intelectual da deliberação racional e a virtude moral da justiça com as quais ele pode contribuir efetivamente para o engrandecimento da cidade. Neste sentido, a concepção grega da liberdade estaria associada à condição de viver de acordo com suas próprias qualidades racionais, a partir das quais o homem livre pode alcançar as mais altas realizaçôes. A participação nos afazeres da cidade se reveste de uma significação moral central, na medida em que é através dela que se estabelece a arena em que os cidadãos podem exercitar suas virtudes intelectuais e morais.

Diferentemente da concepçáo grega, a cidadania e a liberdade entre os romanos seriam pensadas, não como capacidade moral e intelectual, mas como um status do indivíduo reconhecido como cidadão diante de sua comunidade política. $\mathrm{O}$ cidadão seria, portanto, o indivíduo que poderia usufruir do status de homem livre e alguém a quem seria garantido um conjunto de direitos civis e políticos reconhecidos 
pela lei romana. A liberdade seria definida como o status de independência do cidadão, a condição de viver sob a não dominação de outra vontade. Nesta concepçáo, a cidadania não requereria qualidades morais específicas, mas estaria associada ao cultivo da vita activa, através da qual os cidadãos garantiriam a glória de sua pátria e honra para si próprios.

Leitores republicanos contemporâneos da Utopia têm apontado diferentes aspectos na definição da filiação da obra moreana a estas diferentes matrizes do pensamento republicano. A existência da polêmica e da dificuldade de enquadrar claramente a reflexão moreana em alguma destas tradiçóes, demonstra, por si mesmas, o significado de sua novidade no seu tempo. Assim, alguns intérpretes apostam na identificação mais clara da Utopia à matriz romana pelo apontamento das influências de Cícero e Sêneca (PARRISH, 1997; GUY, 2012). Deste ponto de vista, mesmo a leitura mais comum da etimologia da palavra "utopia" cunhada por More, normalmente associada aos radicais gregos ou-topos (não lugar) e eu-topos (lugar feliz), poderia ser relativizada em função de possíveis influências latinas nela contida. Parrish (1997), por exemplo, nota que a influência literária normalmente associada à etimologia da palavra utopia é uma passagem da República de Platão, onde um dos interlocutores de Sócrates afirma que sua república imaginária não poderia ser encontrada em nenhum lugar da terra. Outra, no entanto, poderia ser a passagem chave para se compreender o significado da utopia. Esta seria uma passagem do De otio, de Sêneca, ao expressar sua ideia sobre os méritos da vita contemplativa e da vita activa, especialmente no que diz respeito ao homem sábio. É fato que a obra de Sêneca serviu como fonte clássica para a elaboração de More, o que se torna claro por seu nome e o de Cícero serem citados como únicas referências romanas de Hitlodeu ${ }^{7}$. Para além disto, no entanto, Sêneca, em seu De otio, expressaria uma ideia da participaçáo do homem sábio muito próxima daquela feita por Hitlodeu no Livro I da "Utopia". Depois de haver feito a defesa da vita activa como forma de evitar os males que podem se abater sobre a vida pública, Sêneca expressaria suas desconfianças em relação à participação dos sábios na vida das repúblicas porque a maior parte delas, por náo serem justas, acabam se configurando para estes como um lugar inóspito ou como um "não lugar" (nusquan est).

\footnotetext{
${ }^{7} \mathrm{O}$ autor em questão deixa claro, no entanto, acreditar que a passagem de Sêneca seja uma das que mais diretamente influenciaram More, não constituindo, no entanto, a única obra de referência para ele a este respeito. Ver Parrish (1997, p. 494).
} 
Além da ideia das repúblicas existentes como uma espécie de "não lugar" para os sábios, a influência de Sêneca se expressaria também em diversos princípios apontados por Hitlodeu, como regendo a vida cotidiana dos habitantes da Utopia e que normalmente são associados apenas à adoção, por parte dos utopianos, de uma espécie de cálculo hedonista do epicurismo; segundo o qual se deve "escolher os maiores prazeres sobre os menores e rejeitar os prazeres que resultam em dor" (LOGAN e ADAMS, 2002). Para Parrish (1997), na verdade, boa parte da filosofia moral dos utopianos descrita por Hitlodeu, estaria em desacordo com o epicurismo e mais próxima do estoicismo de Sêneca. Questóes como a crença na existência e providência de um deus, a imortalidade da alma, uma vida posterior em que se recebe puniçóes ou recompensas, a definiçáo da virtude como viver de acordo com os ditames da natureza e da razáo, o cultivo de uma vida de prazeres honestos baseada no tempo livre constituiriam temas tipicamente estoicos, reabilitados pelos humanistas do renascimento.

Diferentemente, outras leituras contemporâneas tomariam a descrição do tipo de organização da vida econômica na república da Utopia para apontar a adesão de More à matriz grega do republicanismo, compartilhado por vários dos humanistas de seu tempo. Na perspectiva de Nelson (2006), por exemplo, enquanto a matriz do republicanismo grego expressaria uma visão da organização da vida pública, em que a inserção ética do cidadão em sua comunidade justificaria a organizaçâo da própria vida econômica em nome desta comunidade; o republicanismo romano, com sua ênfase na autonomia do indivíduo, tenderia à defesa da propriedade individual. A descrição da melhor república como aquela que possuiria fundamentos econômicos organizados pela própria comunidade, significaria que More se posicionaria ao lado da concepção grega endossando o esforço de seu grande amigo Erasmo de Roterdã, em deslegitimar a concepçáo neorromana que havia organizado o pensamento italiano do século XV.

Erasmo de Roterdã teria se lançado num projeto de releitura das escrituras sagradas, recusando particularmente dois valores centrais da tradição neorromana: a teoria romana da justiça e a preocupação romana com honra e glória. A tentativa da civilização cristá, de se reconciliar com estes preceitos, teria degenerado a mensagem das sagradas escrituras resultando na herança de duas patologias romanas: o amor à glória, que resulta nas guerras; e o amor à riqueza, que afasta os homens do ideal da vida em moderação. Para Erasmo de Roterdá, o resultado teria sido a perda, no 
mundo cristão, do sentido grego do bem viver, a eudaimonia, e do próprio sentido da justiça.

Para Nelson (2006), na Utopia, More expressaria essa dicotomia entre fontes gregas e romanas tomando partido, como Erasmo, dos princípios gregos. Rafael Hitlodeu seria o porta voz desta tomada de partido moreana, no Livro I, ao se posicionar em favor das concepções platônicas em relação à participação dos sábios na vida pública e, especialmente, no Livro II, ao apresentar uma forma de organização econômica inserida na concepção do bem geral da república. Desta maneira, More anunciaria uma fissura definitiva no discurso do pensamento político europeu, opondo, de um lado, os defensores da tradição romana com seus valores de independência, propriedade privada e glória e, de outro lado, os defensores da tradição grega para a qual um dos valores centrais seria o da ordem racional do poder público tornado possível pela regulação pública da posse da propriedade.

\section{More na encruzilhada das correntes republicanas}

Do nosso ponto de vista, o impacto e a grandeza da Utopia deveria ser medida não apenas em relação à forma como ela busca se vincular às tradições republicanas de seu tempo, mas também na maneira como realiza sínteses novas e desafia tradiçốes e posicionamentos estabelecidos até então. Chamo a atenção para dois elementos republicanos, não apontados pela literatura sobre a obra de More, que se poderia associar a distintas correntes republicanas de seu tempo, mas que comparecem na Utopia conjuntamente.

O primeiro diz respeito ao fato de que More adota na Utopia uma concepçáo da República "não exclusivista”, ou seja, uma concepção da República, enquanto forma de governo, pré-moderna e mesmo pré-renascentista. Para entender melhor, poder-se-ia apontar uma importante distinção entre o pensamento republicano prémoderno e o moderno, pelo fato de que este último adotaria uma concepção "exclusivista” e não monárquica da República, a partir da compreensão do governo republicano como aquele baseado na vontade do povo e na soberania popular como única fonte legítima de governo (HANKINS, 2010). Tal concepção negaria a legitimidade de qualquer governo não eletivo e, mais especialmente, da forma monárquica de governo e de toda sorte de privilégios políticos hereditários. Este "republicanismo exclusivista" seria típico dos revolucionários norte americanos, como 
Tom Paine, assim como também dos revolucionários franceses do século XVIII e republicanos ingleses do século XVII ${ }^{8}$.

Esta concepção contrastaria com o pensamento republicano pré-moderno para o qual o termo República se aplicaria a uma grande variedade de regimes, tais como: reinados, aristocracias, governos populares e mesmo oligarquias. Entre os gregos, por exemplo, o termo República seria usado para designar formas de constituição mista mais genericamente. O ideal romano da Res Publica, por sua vez, compreendia uma comunidade de pessoas vinculadas por uma lei comum, pelo compartilhamento de um ideal comum de justiça, válido para cada cidadão e por um governo guiado pela busca do bem para todo o povo. Isto náo implicava, contudo, que o governo fosse compartilhado com o povo ou que expressasse sua soberania. Um Príncipe ou Imperador poderia governar plenamente segundo os princípios da Res Publica desde que seu poder se expressasse segundo os parâmetros constitucionais (HANKINS, 2010).

Caberia ao Renascimento italiano fazer a passagem de um republicanismo "não exclusivista" pré-moderno para um "republicanismo exclusivista". Neste momento, emergiria uma nova prática discursiva que tomaria a Res Publica para se referir a governos populares ou governos oligárquicos, ou seja, governos de uma pluralidade de pessoas em oposição aos principados, entendidos como governos de um só. Nicolau Maquiavel seria um dos principais pensadores que popularizaria esta nova prática discursiva a partir de sua descrição dos tipos de governo nos primeiros capítulos do Príncipe.

Embora ele mesmo fosse um grande humanista renascentista e ávido leitor e conhecedor dos humanistas italianos, Thomas More não adotaria na Utopia a prática discursiva do republicanismo exclusivista. As instituiçôes políticas da ilha da Utopia, descritas por Hitlodeu como a melhor República da terra, seriam compostas por um intrincado arranjo de processos eleitorais para escolha de magistrados, senadores e membros das assembleias do povo, mas cuja liderança caberia a um Príncipe, cujo cargo é vitalício. O que tornaria o governo da Utopia uma grande República, como destacaria Hitlodeu, não seria exatamente o fato de que sua legitimidade se assentaria na soberania popular e no governo de muitos, mas numa constituição e numa ordem política altamente vigilante em relação à tentação do Príncipe e dos senadores

\footnotetext{
${ }^{8} \mathrm{Na}$ Inglaterra, terra de More, mais especificamente, John Milton teria sido o responsável por fazer a passagem para uma linguagem republicana exclusivista no século XVII (HANKINS, 2010).
} 
tiranizarem a comunidade. Como destaca Hitlodeu, a principal finalidade das instituiçôes políticas utopianas seria a de impedir que o Príncipe e os senadores possam "conspirar juntos contra a liberdade, oprimir o povo com leis tirânicas e mudar a forma de governo" (MORE, 2002, p. 48).

Em outro aspecto, no entanto, More se aproximaria do republicanismo italiano de seu tempo, mais especificamente, de Maquiavel. Assim como o diplomata florentino, More expressaria, na "Utopia", a percepção da importância do que poderíamos designar como uma "dimensão simbólica do poder" na manutenção de uma ordem política?.

Maquiavel refletiria sobre a importância da dimensão simbólica do poder a partir da temática dos desejos que habitam as cidades humanas: do lado dos grandes, o desejo de oprimir, de comandar; do lado do povo, o desejo de não ser comandado, de não ser oprimido, ou seja, o desejo de liberdade ${ }^{10}$. Toda ordem política especialmente as novas, teria de lidar com o problema desta divisão originária do social. Para Maquiavel, o enfrentamento deste problema se daria na necessidade de forjar a ideia de "povo", recobrindo, com isto, a oposiçáo própria da cidade ao estabelecer uma comunidade aparente para a qual o poder assinala sua identidade. A noção de "povo", neste sentido, constituiria uma unidade fictícia, uma criação simbólica para garantir uma aparência de unidade estabelecida pela linguagem política. Esta seria das mais difíceis missóes do Príncipe, uma vez que, por suas açóes, ele deverá ser capaz de estabelecer uma transcendência do poder graças a qual o povo possa se imaginar e se reconhecer dentro de uma unidade, mas ao mesmo tempo sujeito à realidade da existência da divisão originária. Desta forma, o Príncipe se veria às voltas com a necessidade de estabelecer um imaginário, como efeito de suas boas obras, que torne possível aos homens se reconhecerem numa comunidade política. Para Maquiavel, a dimensão simbólica do poder teria a função de recobrir o abismo das disputas entre o povo e os grandes, tornando possível o estabelecimento de sua identidade e a existência do próprio social.

\footnotetext{
${ }^{9}$ Não é demais observar que Maquiavel se opõe ao gênero literário utópico ao pretender apresentar um realismo político, ao propor-se escrever em "O Príncipe", sobre a veritá effettuale (verdade efetiva das coisas), cujo ponto de partida e chegada seria a realidade concreta, ou seja, a pretensão seria ver e examinar a realidade tal como ela é e não como gostaríamos que ela fosse. Apesar disto, Miguel (2007) nota que a Utopia se aproxima da concepção maquiaveliana ao tomar as instituiçóes sociais e políticas como resultado das ações e escolhas humanas sem apelo a explicações de cunho transcendente.

${ }^{10}$ Para uma discussão sobre o tema da dimensão simbólica do poder no pensamento de Maquiavel a partir da leitura de Claude Lefort, ver Trindade (2013).
} 
More expressa a compreensão da importância dessa dimensão simbólica do poder na manutenção de uma ordem política, ao destacar a importância do papel desempenhado por Utopus, o fundador da Utopia. Esta importância se expressa não só na fundação, mas também na manutenção das instituições políticas e sociais da República utopiana. Utopus forjou uma imagem da República utopiana para seu povo ao estabelecer boas leis, imagem rememorada pelos habitantes da Utopia em seus atos públicos. As instituiçôes políticas seriam também preservadas pelos utopianos do presente, porque sáo cultuadas como o legado de seu fundador e de seus antepassados, ativando a sensibilidade daquilo que transcende a realidade concreta. Não gratuitamente, Utopus teria sido também o criador da doutrina religiosa predominante na Utopia, cuja função primordial seria a de reforçar nos cidadáos as virtudes necessárias para o bom funcionamento das instituições pelo o apelo à dimensão simbólica cultivada nas celebrações públicas ${ }^{11}$.

\section{More e o drama republicano}

Entre as leituras republicanas contemporâneas, caberia a Skinner (1997 e 2003) apontar não apenas como More se filiaria às tradiçóes em disputa no seu tempo, mas também apontar como sua reflexão desarticula tais tradiçôes apontando para novas possibilidades. Na leitura skinneriana, a Utopia pretendia intervir num debate entre duas correntes importantes do pensamento do humanismo renascentista. A primeira seria aquela que faria a defesa da vita contemplativa com base, mais uma vez, em argumentos platônicos. Para esta corrente, os afazeres da vida pública deveriam ser deixados aos cuidados de um guardiáo, o pater patriae, podendo, assim, os indivíduos se entregarem aos prazeres da própria felicidade. Deste ponto de vista, portanto, dada a situação de endêmica degeneração da vida pública, a dedicação aos afazeres privados, a vida do ócio, se tornaria a via privilegiada de realização humana, devendo a vida pública ser deixada para um guardiāo capaz de garantir a ordem necessária aos cidadãos usufruírem de sua vida particular. Por isto mesmo, seria muito comum entre parte dos humanistas italianos o pensamento de que "o governo de um único homem é sempre preferível, mesmo que este homem em questão seja apenas moderadamente bom”.

\footnotetext{
${ }^{11}$ Deste ponto de vista, de fato, é difícil sustentar leituras cristâs da Utopia. Mais correto parece ser a leitura de autores como Nendza (1984) para quem a discussão religiosa na Utopia se dedica a refletir sobre seu papel no estabelecimento de uma República justa.
} 
Em contraste, outra corrente de pensamento entre os humanistas argumentaria que a felicidade do indivíduo não poderia estar salvaguardada caso fosse simplesmente abandonada nas mãos de outro homem. Como a liberdade é algo precioso demais para ser deixada sob responsabilidade de outro, seria necessário que a boa república se sustentasse pela vita activa, ou seja, que os cidadãos tomassem para si a própria responsabilidade de defender publicamente sua autonomia através de instituiçôes republicanas participativas. As fontes para a defesa desta vida de ação, mais uma vez, estariam nos autores romanos, especialmente Sêneca e Cícero. Este último, especialmente em seu De officis, complementaria a ideia grega do cultivo das mais altas qualidades morais como base da cidadania, com a ideia de que muitas destas habilidades só poderiam ser adquiridas na própria ação da vida pública. $\mathrm{Da}$ mesma forma, Cícero, mesmo reconhecendo a importância dos prazeres do ócio privado, se recusaria, no entanto, a estabelecer qualquer grau de prioridade entre estes e os ditames dos afazeres públicos. Antes, a realização destes últimos se impóe como condição de exercício da habilidade e garantia para o usufruto daqueles.

Como a Utopia poderia ser inserida neste debate? Skinner (2003) nota que o próprio More repreende a postura platônica em defesa da vita contemplativa de Hitlodeu, ao final do Livro I, tomando uma linguagem claramente ciceroniana. Neste sentido, More adotaria uma postura neorromana em contraposição, inclusive, à figuras de seu círculo mais próximo como Erasmo de Roterdá. Ele daria, no entanto, passos mais adiante que nos ajudam a compreender o impacto e o significado da novidade estabelecida pela Utopia.

Entre os republicanos neorromanos defensores da vita activa, era comum a defesa de que a qualidade moral, garantidora da virtude para participar dos afazeres públicos, se cultivava na própria participação política e independeria da posse de riqueza como sinal de nobiliarquia e disponibilidade de tempo livre como condição necessária para a formação política. Desta maneira, o republicanismo neorromano afirmaria que posses e riqueza náo seriam condiçóes suficientes para construir o cidadáo virtuoso. Como já observado, More pretenderia se filiar a esta corrente de pensamento, mas, ao fazê-lo, também visaria desestabilizá-la. Isto porque, se seus contemporâneos concordavam que a honra e a glória do cidadáo republicano independem da riqueza, porque continuar a defendê-la ardentemente como faziam? Este será o grande questionamento que More fará através da narrativa de Hitlodeu no Livro II da Utopia. Ali, o fictício viajante português nos fará saber que, de fato, a honra e a glória do cidadáo numa República bem ordenada independem da posse da riqueza e, por isto mesmo, náo faz sentido defendê-la, como ainda faziam os 
humanistas contemporâneos de More. Pelo contrário, a defesa da riqueza, do luxo e da superficialidade típicas das sociedades cristâs europeias, seriam fontes de vários dos vícios que não se verificariam na República da Utopia, uma vez que ali a virtude seria resguardada pela própria sociedade.

Deste ponto de vista, o grande significado da "Utopia" pode ser encontrado no fato de que ela se constitui como uma obra que desestabiliza as tradiçôes do pensamento político do seu tempo, ecoando questôes que chegam aos nossos dias. Como observa Skinner (2003), More faz um desafio grave a seus contemporâneos: se a posse de riqueza e luxo não é condição necessária para o cultivo das virtudes e se elas são fontes de vários dos vícios que assolam a vida pública, sua defesa irrestrita é incompatível com os anseios da construção da melhor república. $\mathrm{O}$ fato de que More reconhece, ao final da narrativa, a impraticabilidade dos princípios que norteiam as instituiçôes utopianas nas sociedades europeias significaria, também, que estas sociedades estariam condenadas a não melhorar suas repúblicas. Neste aspecto, de fato, como apontam Logan e Adams (2002), a Utopia se posiciona, na história do pensamento político ocidental, como uma obra melancólica porque condenada, desde o início, a ser derrotada pelas forças políticas hegemônicas em seu tempo.

\section{Conclusão}

Ao longo deste trabalho procuramos mostrar como os avanços contemporâneos do que estamos designando como leituras republicanas da Utopia, apontam para chaves interpretativas da obra moreana muitas vezes obscurecidas pela leitura liberal. A partir daqui, podemos retomar as duas principais críticas comumente feitas pela leitura liberal à "Utopia".

A primeira, como já assinalamos, diz respeito à acusação de que More prescreveria um ideal de "perfectibilidade", ou seja, uma receita da construção de uma sociedade perfeita tornada matéria manipulável para regimes políticos desrespeitarem direitos individuais em nome de um bem maior. A resposta à esta questáo envolve, primeiramente, o reconhecimento de concepçôes mais generosas da noção de perfectibilidade que a entendam não como o estabelecimento da perfeição através de uma força externa, mas como a busca do "melhor possível" (LEPOJARVI, 2011). Deste ponto de vista, seria necessário reconhecer que determinadas forças e estruturas materiais e sociais, necessariamente influenciam comportamentos e alteram a vida das pessoas para melhor ou para pior, dependendo de determinados contextos. Da mesma forma, essas estruturas e instituiçóes sociais podem ser mobilizadas para 
estimular formas de vida e o cultivo de virtudes compatíveis com o que desejamos como ordem política, por exemplo, tolerância e respeito aos direitos fundamentais. Como deixa claro o próprio subtítulo da obra, o que More busca é exatamente "a melhor república", não a perfeita. Além disto, a narrativa de Hitlodeu nos dá conta de que a republicana utopiana não é simplesmente reproduzível, ela não é modelo a ser copiado porque não foi fruto de simples engenho racional, mas envolveu também a ação do acaso, como a grande virtude de seu fundador Utopus, não podendo, portanto, ser puramente copiada.

Em segundo lugar, há a crítica liberal de que More estabelece o ideal de uma sociedade fora da história, porque sendo ela perfeita, também é imutável. Tal crítica não condiz com o narrado na obra. Mais correto seria pensar a narrativa de Hitlodeu sobre a república da Utopia como o retrato de um tempo, porque, como afirma o navegante português em relação à adoção do cristianismo pelos utopianos, se voltarmos lá provavelmente os veremos diferentes do que eram.

Por fim, resta para nós, 500 anos depois da publicação deste marco do pensamento político ocidental, o desafio de repensar nossas repúblicas nas condiçóes em que as democracias contemporâneas são sitiadas pelo poder econômico e em sociedades que abandonaram a ideia republicana fundamental de que a arte do bem viver em comum envolve o cultivo das virtudes públicas. Este, na verdade, constitui o grande legado desta obra fundamental para os dias de hoje.

- Gleyton Trindade é Professor Adjunto de Ciência Política da Universidade Federal de Alfenas (MG). E-mail: gleytontrindade@ hotmail.com. 


\section{Referências}

ABENSOUR, Miguel. O Novo Espírito Utópico. Editora da Unicamp, 1990.

BERLIN, Isaiah. Decline of utopian ideas in the West. The Japan Foundation, 1978.

FRAGA, Paulo Denisar. Utopia. In: FENSTERSEIFER, Paulo Evaldo; GONZÁLEZ, Fernando Jaime (Orgs.). Dicionário crítico de Educaçâo Física. Ed. Unijuí, 2014, p. 665-671.

GUY, John. Thomas More and tyranny. Moreana, v. 49, n. 189-190, p. 157-188, 2012.

HANKINS, James. Exclusivist republicanism and the non-monarchical republic. Political Theory, v. 38, n. 4, p. 452-482, 2010.

HONOHAN, Iseult. Civic Republicanism. Routledge, 2003.

KUMAR, Krishan. Aspects of the Western utopian tradition. History of the Human Sciences, v. 16, n. 1, p. 63-77, 2003.

LEOPOLD, David. Socialism and (the rejection of) utopia. Journal of Political Ideologies, v. 12, n. 3, p. 219-237, 2007.

LEPOJARVI, Jason. Utopia reconsidered: two levels of perfection in society. Theology Today, v. 68, n. 2, p. 174-180, 2011.

LOGAN, George; ADAMS, Robert. Introduction. In: MORE, Thomas. Utopia. Cambridge University Press, 2002. p. xi-xxix.

MIGUEL, Luís Felipe. O nascimento da política moderna: Maquiavel, utopia, reforma. Ed. da UnB, 2007.

MORE, Thomas. A Utopia. Nova Cultural, 1988.

. Utopia. Cambridge University Press, 2002.

Utopia. Ed. Autêntica, 2017.

NELSON, Eric. Utopia through Italian eyes: Thomas More and the critics of Civic Humanism. Renaissence Quarterly, v. 59, n. 4, p. 1029-1057, 2006.

NENDZA, James. Religion and Republicanism in More's Utopia. Western Political Quarterly, v. 37, n. 2, p. 195-211, 1984.

PARRISH, John. A new source for More's 'Utopia'. The Historical Journal, v. 40, n. 2, p. 493-498, 1997.

PETTIT, Philip. Republicanism: a theory of freedom and government. Oxford University Press, 1997.

POPPER, Karl. A sociedade aberta e seus inimigos. Itatiaia, 1987.

ROTHSTEIN, Edward; MUSCHAMP, Herbert; MARTY, Martin. Visions of Utopia, Oxford University Press, 2003.

SARGENT, Lyman Tower. In defense of Utopia. Diogenes, v. 53, n. 1, p. 11-17, 2006.

Five hundred years of Thomas More's Utopia and Utopianism. Utopian Studies, v. 27, n.

2, p. 184-198, 2016.

SHKLAR, Judith. The political theory of Utopia: from melancholy to nostalgia. Daedalus, v. 94, n. 2, p. 367-381, 1965.

SKINNER, Quentim. Sir Thomas More's Utopia and the language of Renaissance Humanism. In:

PAGDEN, Anthony. The languages of political theory on early-modern Europe. Cambridge University Press, 1997, p. 123-158.

Liberdade antes do liberalismo. Ed. da Unesp, 1999. 
168 | Gleyton Trindade

Visions of Politics. Cambridge University Press, 2003.

TRINDADE, Gleyton. Maquiavel e a dimensão simbólica do poder: fundamentos da teoria democrática de C. Lefort. Revista Brasileira de Ciência Política, n. 12, p. 155-180, 2013.

Texto recebido em 25 de outubro de 2017. Aprovado em 03 de abril de 2018. 